\title{
Analisis penguasaan kompetensi kewarganegaraan pada mahasiswa PPKn Universitas PGRI Madiun
}

\author{
Yoga Ardian Feriandi ${ }^{a, 1^{*}}$, Yuni Harmawati ${ }^{\mathrm{b}, 2}$ \\ a,b Universitas PGRI, Madiun \\ ${ }^{1}$ yogaardianferiandi@unipma.ac.id; ${ }^{2}$ yuniharmawati@unipma.ac.id \\ ${ }^{*}$ Korespondensi penulis
}

\begin{abstract}
ABSTRAK
Penelitian ini berupaya untuk menganalisis penguasaan civic competence (civic knowledge, civic disposition, civic skill) pada mahasiswa PPKn. Metode yang digunakan dalam penelitian ini adalah metode kombinasi menggunakan model campuran tidak berimbang (Concurrent embedded). Subjek dalam penelitian ini adalah semua mahasiswa jurusan PPKn di Universitas PGRI Madiun. Untuk mengumpulkan data dari subjek yang ada maka metode yang digunakan adalah wawancara, observasi, dan dokumentasi. Sedangkan untuk menganalisis data digunakan teknik interaktif Miles and Huberman, serta analisis deskriptif persentase. Hasil dari penelitian menunjukkan bahwa secara keseluruhan mahasiswa PPKn semester VII lebih baik dalam penguasaan Civic Competence di banding mahasiswa PPKn di semester lain. Hal itu karena dalam kelas mereka telah dikembangkan kultur demokratis seperti aktif dalam pengambilan keputusan publik, ikut dalam diskusi antara mahasiswa dan kampus, aktif dalam kegiatan kemahasiswaan (BEM, HMPS), serta aktif dalam berbagai organisasi sosial di luar kampus. Sehingga secara tidak langsung berbagai aktivitas yang telah mereka lakukan tersebut dapat membantu untuk mengembangkan civic competence.
\end{abstract}

Kata kunci: civic competence, knowledge, skill, disposition

\section{ABSTRACT}

This study attempts to analyze the mastery of Civic Competence (Civic Knowledge, Civic Disposition, Civic Skill) in PPKn students. The method used in this study is a combination method using an unbalanced (Concurrent embedded) mixed model. Subjects in this study were all students majoring in PPKn at the University of PGRI Madiun. To collect data from existing subjects, the methods used are interviews, observation, and documentation. Whereas to analyze the data used, Miles and Huberman interactive techniques, as well as descriptive percentage analysis. The results of the study show that overall semester VII PPKn students are better in mastering Civic Competence than PPKn students in other semesters. It is because in their class a democratic culture has been developed such as being active in public decision making, participating in discussions between students and campus, active in student activities (BEM, HMPS), and active in various social organizations off-campus. So that indirectly various activities that they have done can help to develop Civic Competence

Keywords: civic competence, knowledge, skill, disposition

Copyright $(02018$ Universitas Ahmad Dahlan, All Right Reserved

\section{PENDAHULUAN}

Hampir semua negara yang menganut paham demokrasi menginginkan untuk mengembangkan konsep Civil Society. Konsep civil society merupakan suatu tempat terhimpunnya kekuatan masyarakat untuk mempertahankan kebebasan, keanekaragaman, serta kemandirian masyarakat terhadap kekuasaan negara dan pemerintah (Alam, 2006). Sehingga untuk dapat mewujudkan konsep civil society tersebut di perlukan peran warga negara yang memiliki kompetensi kewarganegaraan (civic competence) yang baik.

Dalam upaya untuk meningkatkan kompetensi kewarganegaraan salah satunya dilakukan dengan cara mengajarkan pendidikan kewarganegaraan kepada masyarakat agar memiliki kompetensi kewarganegaraan yang di dalamnya terdiri dari civic knowledge, civic skill, dan civic disposition (Branson \& Quigley, 1998). Ketiga komponen yang tergabung dalam kompetensi kewarganegaraan tersebut merupakan komponen penting yang akan membentuk warga negara untuk dapat melaksanakan hak dan kewajiban secara proporsional. Sehingga dapat dikatakan dengan membekali warga negara untuk memiliki kompetensi kewarganegaraan maka secara langsung juga memperbaiki human capital Indonesia yang sangat diperlukan guna menunjang kehidupan berdemokrasi.

Salah satu bagian dari kompetensi kewarganegaraan yakni adanya pengetahuan kewarganegaraan (civic knowledge). Bagian ini sangat erat kaitannya dengan pengetahuan dan pemahaman yang wajib dimiliki oleh setiap individu, sebab berfungsi untuk memahami hak dan kewajiban sebagai warga negara, sehingga dapat memberikan efek positif dan gambaran mengenai 
penggunaan hak pilih pada masa yang akan datang pada pelajar (Sherrod, Torney-Purta, Lehmann, Oswald, \& Schulz, 2001). Jika diuraikan secara spesifik, maka materi mengenai pengetahuan kewarganegaraan meliputi beberapa hal seperti hak dan tanggung jawab warga negara, hak asasi manusia. Prinsip-prinsip dan proses demokrasi, pemerintah dan nonpemerintah, identitas nasional, pemerintahan berdasar hukum (rule of law) dan peradilan yang bebas dan tidak memihak, konstitusi, serta nilai-nilai dan norma-norma dalam masyarakat.

Pengetahuan kewarganegaraan diperoleh warga negara dari berbagai macam aktivitas, termasuk pada jenjang persekolahan terutama melalui pelajaran PPKn. Namun selain itu aktivitas lain seperti membaca berita mengenai masalahmasalah kewarganegaraan sebenarnya juga meningkatkan pengetahuan kewarganegaraan (Galston, 2007). Sehingga pengetahuan kewarganegaraan yang diperoleh seorang warganegara tidak hanya berasal dari jenjang persekolahan melainkan juga dari berbagai macam aktivitas lain di luar persekolahan. Meski demikian persekolahan tetap memberikan dampak penting untuk dapat mengarahkan aktivitas-aktivitas siswa di luar sekolah agar dapat memiliki pengetahuan kewarganegaraan.

Civic skill (keterampilan warganegara) merupakan keterampilan yang dikembangkan dari pengetahuan kewarganegaraan, agar pengetahuan yang diperoleh menjadi sesuatu yang bermakna, karena dapat dimanfaatkan dalam menghadapi masalah kehidupan berbangsa dan bernegara (Budiarta, 2013). Keterampilan kewarganegaraan terbentuk dari akumulasi pengetahuan dan pemahaman warga negara yang akan berbanding lurus terhadap wawasan, sehingga membentuk pola berpikir kritis pada siswa. Pendapat Komalasari (2013) yang merujuk pada National Standards For Civics Framework For 1988 National Assesment Of Educational Progress (NAEP) menegaskan bahwa keterampilan berfikir kritis sebagai civic skill meliputi keterampilan mengidentifikasi, menggambarkan, mendeskripsikan, menjelaskan, menganalisis, mengevaluasi, menentukan, mempertahankan pendapat yang berkenaan dengan masalah-masalah publik.

Pada intinya keterampilan warganegara ini sangat membantu untuk dapat mengontrol jalanya pemerintahan, seperti bagaimana mengemukakan pendapat, kritikan, saran untuk kemajuan umum. Melatih keterampilan warganegara sebenarnya juga telah diprogramkan dalam berbagai macam kegiatan pendidikan di sekolah, seperti adanya program Adiwiyata bakti, dimana sekolah berkompetisi untuk menjadi sekolah paling ramah lingkungan yang secara bersamaan juga meningkatkan keterampilan warganegara terkait dengan perlindungan lingkungan (Feriandi, 2018).

Keterampilan kewarganegaraan ini sangat penting bagi warganegara utamanya di era saat ini, warganegara memang memahami dan memiliki pengetahuan kewarganegaraan yang cukup namun belum mampu untuk memiliki keterampilan untuk mengemukakan pengetahuannya dengan tepat, sehingga acap kali kita jumpai kritikan yang berujung pada tindak pidana karena di nilai menyinggung pihak lain.

Civic disposition (watak kewarganegaraan) merupakan komponen ketiga dari kompetensi kewarganegaraan yang timbul dari proses akumulasi dari civic knowledge dan civic skill. Konsep watak kewarganegaraan akan selalu berhubungan dengan karakter warga negara di ruang publik dan privat dalam ruang lingkup demokrasi. Watak kewarganegaraan sebagai komponen dari kompetensi kewarganegaraan dapat di kembangkan di lingkungan sekolah, keluarga dan masyarakat. Pada ruang publik, watak kewarganegaraan dapat diukur melalui tingkat kesadaran sebagai warga negara, patuh terhadap hukum, berfikir kritis, kesopanan, kemampuan untuk menjadi pendengar yang baik, dan kemampuan untuk berkompromi, sedangkan di ruang privat meliputi tanggung jawab moral, kedisiplinan dan menjunjung tinggi harkat dan martabat manusia.

Terkait dengan watak kewarganegaraan tersebut sekolah dapat mengambil peran utama dalam proses pembentukannya, misalnya melalui pelaksanaan ekstra kurikuler seperti Paskibra, jurnalistik, ROHIS dan KIR (Lestari, 2016), bahkan bisa di peroleh melalui budaya-budaya yang sebenarnya telah ada dan berkembang di sekitar misalnya dari budaya Jawa. Hasil kajian yang dilakukan oleh Feriandi (2018); Budiyono \& Feriandi (2017), dan Huda \& Feriandi (2018) menunjukkan bahwa masyarakat dapat menggali nilai-nilai karakter pada slogan-slogan dan tutur kata bahasa jawa, yang mana hal tersebut juga dapat mempengaruhi watak seseorang.

Terkait dengan kompetensi kewarganegaraan, hasil penelitian dari ICCS tentang kondisi pendidikan kewarganegaraan di lima tempat negara (Indonesia, Hong Kong SAR, Republik Korea/Korea Selatan, Taiwan, dan Thailand) menyebutkan bahwa hasil tes pengetahuan pendidikan kewarganegaraan (Civic knowledge) di Indonesia dan Thailand pada siswa kelas VIII lebih rendah jika dibandingkan dengan negara sampel lainnya di Asia (Fraillon, Schulz, \& Ainley, 2012). Berbicara mengenai hasil yang diperoleh siswa tersebut maka sebenarnya tidak lepas dari faktor 
guru khususnya guru pendidikan Kewarganegaraan, karena guru lah yang berperan langsung dalam mengembangkan siswanya. Untuk itu pada artikel ini akan mencoba menganalisis kompetensi kewarganegaraan dari mahasiswa PPKn, karena pada saatnya nanti merekalah yang bertugas untuk mendidik siswa agar dapat menguasai kompetensi kewarganegaraan dengan baik.

\section{METODE}

Jenis penelitian yang digunakan dalam penelitian ini adalah metode penelitian kombinasi (mixed methods) dengan model concurrent embedded (campuran tidak berimbang). Sugiyono (2009) menyatakan bahwa "metode kombinasi model concurrent embedded (campuran tidak berimbang) adalah metode penelitian yang menggabungkan antara metode penelitian kualitatif dan kuantitatif dengan cara mencampur kedua metode tersebut secara tidak seimbang". Penelitian ini lebih menekankan pada pendekatan kualitatif yang kemudian didukung oleh pendekatan kuantitatif. Subjek dalam penelitian ini adalah semua mahasiswa jurusan PPKn di Universitas PGRI Madiun. Untuk mengumpulkan data dari subjek yang ada maka metode yang digunakan adalah wawancara, observasi, dan dokumentasi.

\section{HASIL DAN PEMBAHASAN}

\section{Pengetahuan Kewarganegaraan (Civic Knowledge)}

Dari hasil analisis angket yang telah disebarkan ke pada 50 responden mahasiswa PPKn universitas PGRI Madiun, maka dapat diketahui bahwa semester VI mendapatkan skor paling tinggi di banding semester lain yakni dengan rerata 85,29 sedangkan semester II 66, semester III 79,36, dan semester VIII 71,29. Dari hasil kuantitatif tersebut kemudian data penelitian di tambah melalui proses kualitatif yakni melalui wawancara. Hasil wawancara dengan siswa semester VI diketahui bahwa nilai tinggi dalam pengetahuan kewarganegaraan di peroleh dari telah lama menekuni ilmu tentang kewarganegaraan selama kuliah yang di padukan dengan praktik-praktik kewarganegaraan seperti diskusi di forum mahasiswa, debat masalah publik, bakti sosial, kunjungan ilmiah, dan seminar yang ternyata tidak terlalu banyak dilakukan oleh semester lain. Selain itu penguasaan pengetahuan kewarganegaraan yang lebih baik juga di sebabkan karena banyak dari mereka aktif bekerja sebagai pengajar paruh waktu di berbagai bimbingan belajar. Hal itu di ungkapkan oleh Nurma yang merupakan salah satu responden yang mengatakan bahwa "Selain kuliah, saya juga mengisi waktu saya dengan bekerja paruh waktu sebagai tentor dalam lembaga bimbingan belajar, ketika menjadi tentor saya mengajarkan berbagai mata pelajaran dengan berbagai tingkatan. Ketika saya mengajar SD selain mengajarkan PPKn saya juga mengajar IPS sehingga memaksa saya untuk selalu mengembangkan diri dengan belajar. Sehingga secara tidak langsung meningkatkan pengetahuan kewarganegaraan saya". Hal senada juga di ungkapkan oleh Hana yang mengatakan bahwa "Selain kuliah saya juga mengajarkan mata pelajaran PPKn pada berbagai siswa sekolah, karena dalam PPKn mengajarkan hal-hal pokok mengenai Warganegara maka hal tersebut juga sekaligus mengembangkan pengetahuan kewarganegaraan saya".

Dari temuan tersebut maka juga sekaligus membuktikan bahwa dengan mengajarkan pengetahuan yang dimiliki justru dapat membuat pemahaman seseorang semakin meningkat, karena seseorang secara terus menerus akan berusaha untuk mengingat dan meningkatkan pemahaman akan ilmunya tersebut. Selain itu pengetahuan kewarganegaraan dapat diketahui bahwa penguasaannya tidak semata-mata diperoleh dari proses kognitif pembelajaran di kelas semata melainkan juga di bentuk karena kegiatan-kegiatan lain yang berkaitan dengan pengetahuan kewarganegaraan.

Hasil wawancara pada mahasiswa semester II menunjukkan bahwa di tingkat ini mereka mengembangkan pengetahuan kewarganegaraan hanya dari materi yang diberikan di perkuliahan semata, kurang ada upaya untuk mengembangkan keilmuannya secara positif seperti mengajar atau mengikuti diskusi di forum mahasiswa, debat masalah publik, bakti sosial, kunjungan ilmiah, dan seminar. Hal serupa juga terjadi pada mahasiswa semester IV dan VII namun kondisinya lebih baik daripada mahasiswa semester II karena lebih lama menekuni bidang Pendidikan Kewarganegaraan dibanding semester II. Untuk rekapitulasi lebih jelas dapat dilihat pada tabel 1 di bawah ini. 
Tabel 1 Rekapitulasi Pengetahuan Kewarganegaraan

\begin{tabular}{|c|c|c|c|c|c|}
\hline & & $\begin{array}{c}\text { Pengetahuan } \\
\text { Kewarganegaraan } \\
\text { semester } 2 \\
\end{array}$ & $\begin{array}{c}\text { Pengetahuan } \\
\text { Kewarganegaraan } \\
\text { semester } 4\end{array}$ & $\begin{array}{c}\text { Pengetahuan } \\
\text { Kewarganegaraan } \\
\text { semester } 6\end{array}$ & $\begin{array}{c}\text { Pengetahuan } \\
\text { Kewarganegaraan } \\
\text { semester } 8\end{array}$ \\
\hline \multirow{2}{*}{$N$} & Valid & 8 & 11 & 17 & 7 \\
\hline & Missing & 0 & 0 & 0 & 0 \\
\hline \multicolumn{2}{|l|}{ Mean } & 66.0000 & 79.3636 & 85.2941 & 71.2857 \\
\hline \multicolumn{2}{|l|}{ Median } & 71.0000 & 86.0000 & 86.0000 & 71.0000 \\
\hline \multicolumn{2}{|c|}{ Mode } & 71.00 & 86.00 & $71.00^{\mathrm{a}}$ & 64.00 \\
\hline \multicolumn{2}{|c|}{ Std. Deviation } & 16.05348 & 14.17937 & 12.38328 & 8.51889 \\
\hline \multicolumn{2}{|c|}{ Minimum } & 36.00 & 43.00 & 64.00 & 64.00 \\
\hline \multicolumn{2}{|c|}{ Maximum } & 86.00 & 93.00 & 100.00 & 86.00 \\
\hline \multicolumn{2}{|c|}{ Sum } & 528.00 & 873.00 & 1450.00 & 499.00 \\
\hline
\end{tabular}

Sumber: Data hasil penelitian, 2018.

\section{Keterampilan Kewarganegaraan (Civic Skill)}

Dari data yang di himpun, diketahui bahwa mahasiswa semester VI memiliki rerata paling bagus terkait dengan penguasaan keterampilan kewarganegaraan. Selain melalui mata pelajaran Pendidikan Kewarganegaraan, keterampilan kewarganegaraan sendiri menurut teori dapat di kuasai siswa melalui beberapa aktivitas yang dilakukan oleh siswa. Misalnya seperti ikut aktif dalam organisasi masyarakat / siswa, turut serta dalam proses politik (pemilu/pemungutan suara/musyawarah), dan ikut serta dalam berbagai diskusi. Sehingga dapat di pahami jika siswa aktif serta dalam berbagai kegiatan tersebut keterampilan kewarganegaraannya juga akan dapat meningkat. Hal itu sesuai dengan hasil penelitian ini yang menunjukkan bahwa mahasiswa semester VI memiliki rerata nilai paling baik dalam kategori Civic Skill yakni sebesar 74,30 sedangkan Semester II 54,00 Semester IV 67,00 dan Semester VIII 60,00.

Dari hasil wawancara dan observasi diketahui memang banyak siswa semester VI yang ikut aktif dalam organisasi masyarakat / siswa, turut serta dalam proses politik (pemilu/pemungutan suara/musyawarah), dan ikut serta dalam berbagai diskusi. Contohnya beberapa siswa dari semester VI di tunjuk sebagai perwakilan fakultas untuk mengikuti diskusi dengan rektorat untuk membahas kebijakan universitas. Bahkan salah ada mahasiswa yang di tunjuk sebagai fasilitator guna mencari titik temu keinginan dari mahasiswa dan pihak universitas yang pada akhirnya membuahkan beberapa perubahan kebijakan seperti biaya magang, serta sarana prasarana kampus.

Karena telah terbiasa aktif dalam berbagai forum untuk mencari solusi dan pemecahan permasalahan sosial di kampus pada akhirnya hal tersebut terbawa pada kehidupan di luar kampus. Hal tersebut di kuatkan dengan hasil dari wawancara dengan salah satu mahasiswa semester VI yang mengatakan bahwa kebiasaannya aktif berdiskusi di kampus pada akhirnya juga terbawa saat dia di masyarakat, dia tidak segan lagi untuk mengutarakan pendapatnya demi kemajuan masyarakat ketika di forum.

"Setelah aktif mengikuti organisasi di kampus, Saya sekarang lebih berani dalam mengungkapkan pendapat ketika di desa saya sedang membahas persoalan-persoalan sosial, padahal saya dahulu lebih memilih diam ketika ditanya pendapat terkait suatu persoalan"

Sedangkan pada semester lain penguasaan keterampilan kewarganegaraan hanya di peroleh dari bacaan-bacaan mengenai pendidikan kewarganegaraan yang notabene memiliki muatan keterampilan kewarganegaraan seperti buku tersebut termuat dalam bentuk uraian materi, ilustrasi gambar, maupun soal. Buku bacaan memang terbukti dapat memberikan mahasiswa untuk memiliki civic skill hal tersebut sesuai dengan penelitian yang dilakukan oleh Prihastari (2016), yang menyebutkan bahwa buku-buku pendidikan kewarganegaraan memiliki dimensi keterampilan kewarganegaraan yang dapat melatih kemampuan untuk mewujudkan warga negara yang baik, keterampilan melakukan monitoring jalannya pemerintahan, keterampilan dalam mengambil keputusan, keterampilan pemecahan masalah sosial, keterampilan berkoalisi dan mengelola konflik yang mana kemampuan tersebut merupakan bagian dari civics skill. Untuk lebih lengkap dapat dilihat pada tabel 2 berikut ini. 
Tabel 2. Rekapitulasi Penilaian Keterampilan Kewarganegaraan

\begin{tabular}{|c|c|c|c|c|c|}
\hline & & $\begin{array}{c}\text { Keterampilan } \\
\text { Kewarganegaraan } \\
\text { semester } 2\end{array}$ & $\begin{array}{c}\text { Keterampilan } \\
\text { Kewarganegaraan } \\
\text { semester } 4\end{array}$ & $\begin{array}{c}\text { Keterampilan } \\
\text { Kewarganegaraan } \\
\text { semester } 6\end{array}$ & $\begin{array}{c}\text { Keterampilan } \\
\text { Kewarganegaraan } \\
\text { semester } 8\end{array}$ \\
\hline \multirow{2}{*}{$N$} & Valid & 8 & 11 & 17 & 7 \\
\hline & Missing & 0 & 0 & 0 & 0 \\
\hline \multicolumn{2}{|l|}{ Mean } & 54.0000 & 67.8182 & 74.2941 & 60.7143 \\
\hline \multicolumn{2}{|l|}{ Median } & 54.0000 & 67.0000 & 75.0000 & 58.0000 \\
\hline \multicolumn{2}{|c|}{ Mode } & $45.00^{\mathrm{a}}$ & 67.00 & 77.00 & $55.00^{\mathrm{a}}$ \\
\hline \multicolumn{2}{|c|}{ Std. Deviation } & 7.11136 & 6.58511 & 6.04943 & 5.87975 \\
\hline \multicolumn{2}{|c|}{ Minimum } & 45.00 & 60.00 & 63.00 & 55.00 \\
\hline \multicolumn{2}{|c|}{ Maximum } & 65.00 & 85.00 & 90.00 & 70.00 \\
\hline \multicolumn{2}{|c|}{ Sum } & 432.00 & 746.00 & 1263.00 & 425.00 \\
\hline
\end{tabular}

Sumber: Data hasil penelitian, 2018.

\section{Watak Kewarganegaraan (Civic Disposition)}

Dari data tersebut, diketahui bahwa mahasiswa semester IV Memiliki rerata paling bagus terkait dengan penguasaan watak kewarganegaraan. Watak kewarganegaraan berkaitan dengan sikap, watak dari warga negara. Karakter kewarganegaraan ini termasuk kedalam karakter privat seperti tanggung jawab moral, disiplin serta penghargaan terhadap harkat dan martabat manusia dari setiap individu (Winataputra \& Budimansyah, 2012). Watak kewarganegaraan ini dapat ditingkatkan melalui pembiasaan sehari hari maupun mencontoh suri teladan yang ada di sekitar lingkungan siswa. Misalnya sejak dini orang tua sudah membiasakan hal-hal yang baik sehingga siswa setelah besar melekat sebagai watak yang sudah dimilikinya. Contohnya menanamkan sejak dini sifat bertanggung jawab, disiplin serta menghormati orang yang lebih tua. Sehingga ketika siswa telah dewasa dan tinggal di tempat yang baru dengan lingkungan yang baru siswa dapat beradaptasi serta tetap melestarikan watak yang baik yang sudah ditanamkan oleh orang tuanya sejak dini. Hal itu sesuai dengan hasil penelitian ini yang menunjukkan bahwa mahasiswa semester IV memiliki rerata nilai paling baik dalam kategori watak kewarganegaraan yakni sebesar 71,72 sedangkan Semester II 57,25 Semester VI 68,35 dan Semester VIII 67,42.

Dari hasil wawancara dan observasi diketahui memang banyak siswa semester IV peran orang tuanya sangat mendukung pembentukan karakter siswa sejak dini. Pendidikan yang paling utama sebagai fondasi adalah pendidikan dalam keluarga. Karakter siswa akan terbentuk dengan baik ketika sang orang tua atau keluarga ini sudah melakukan pembiasaan semenjak kecil begitu juga sikap keteladanan dari orang tuanya sendiri.

"Sejak kecil saya sudah diajarkan bagaimana jujur itu harus didahulukan. Meskipun hasilnya kurang memuaskan tetapi yang terpenting adalah jujur. Orang tua saya tidak pernah memaksakan nilai saya harus bagus tetapi bagaimana saya mengerjakan ujian dengan jujur dan dapat mempertanggungjawabkannya dengan baik"

Sedangkan pada semester lain penguasaan watak kewarganegaraan kurang maksimal, hal ini banyak faktor yang mempengaruhi. Misalnya ada beberapa siswa yang tinggal bukan bersama orang tuanya, dari kecil orang tua mereka sudah berada di luar negeri untuk mencari nafkah kemudian mereka dititipkan kepada nenek ataupun saudara yang lain. Dengan demikian rasa kasih sayang yang mereka dapatkan kurang serta orang tua kurang mendukung penanaman karakter yang seharusnya dilakukan semenjak dini. Kemudian peran sekolah dalam mengembangkan karakter kewarganegaraan hanya membantu atau meneruskan pendidikan dalam keluarga siswa. Dalam penelitian Lukitoaji (Lukitoaji, 2017) bahwa dalam pembinaan watak kewarganegaraan atau karakter kewarganegaraan di dalam kelas dibelajarkan melalui model pembelajaran project citizen dalam mata kuliah Pendidikan Kewarganegaraan yang memiliki nilai moral pada mahasiswa. Beberapa watak kewarganegaraan yang muncul dalam pembelajaran PKn dengan model pembelajaran project citizen adalah tanggung jawab, disiplin, penghargaan terhadap harkat dan martabat manusia, kepedulian, kesopanan, berpikir kritis, kemauan mendengar, bernegosiasi, serta berpartisipasi dalam masalah bersama dengan cara yang terbuka.

Kemudian watak kewarganegaraan dapat dilakukan dengan pembiasaan nilai-nilai Pancasila dalam kehidupan sehari-hari. Nilai-nilai tersebut adalah nilai ketuhanan, nilai kemanusiaan, nilai kebersamaan/ gotong royong, nilai kebersamaan dalam bermusyawarah mufakat serta nilai keadilan. Selain itu mengetahui makna kearifan lokal peserta didik juga berpengaruh terhadap karakter siswa. Seperti yang tercantum dalam hasil penelitian Harmawati, Abdulkarim, \& Rahmat (2017) bahwa nilai kearifan lokal mempunyai relevansi dengan pembangunan karakter bangsa. Kearifan lokal 
merupakan nilai yang berlaku dan diyakini dalam suatu masyarakat serta menjadi acuan bertingkah laku dalam kehidupan sehari-hari. Jika mampu memahami kearifan lokal di setiap daerahnya, maka tidak menutup kemungkinan kearifan lokal tersebut dapat meningkatkan nilai karakter atau watak kewarganegaraan mahasiswa.

Tabel 3 Rekapitulasi Penilaian Watak Kewarganegaraan

\begin{tabular}{|c|c|c|c|c|c|}
\hline & & $\begin{array}{c}\text { Watak } \\
\text { Kewarganegaraan } \\
\text { semester } 2 \\
\end{array}$ & $\begin{array}{c}\text { Watak } \\
\text { Kewarganegaraan } \\
\text { semester } 4\end{array}$ & $\begin{array}{c}\text { Watak } \\
\text { Kewarganegaraan } \\
\text { semester } 6\end{array}$ & $\begin{array}{c}\text { Watak } \\
\text { Kewarganegaraan } \\
\text { semester } 8 \\
\end{array}$ \\
\hline \multirow{2}{*}{$N$} & Valid & 8 & 11 & 17 & 7 \\
\hline & Missing & 0 & 0 & 0 & 0 \\
\hline Mean & & 57.2500 & 71.7273 & 68.3529 & 67.4286 \\
\hline Median & & 55.0000 & 72.0000 & 67.0000 & 69.0000 \\
\hline Mode & & 52.00 & $68.00^{\mathrm{a}}$ & 73.00 & 69.00 \\
\hline Std. Deviatior & & 6.64938 & 4.47417 & 4.99926 & 2.76026 \\
\hline Minimum & & 52.00 & 64.00 & 61.00 & 64.00 \\
\hline Maximum & & 70.00 & 79.00 & 79.00 & 71.00 \\
\hline Sum & & 458.00 & 789.00 & 1162.00 & 472.00 \\
\hline
\end{tabular}

Sumber: Data hasil penelitian, 2018.

\section{Kompetensi Kewarganegaraan (Civic Competence)}

Kompetensi kewarganegaraan atau biasa disebut dengan kompetensi warga negara merupakan kompetensi yang harus dimiliki oleh semua warga negara untuk dapat menunjang kehidupan berdemokrasi. Kompetensi kewarganegaraan ini wajib dikuasai oleh peserta didik baik itu pengetahuan, nilai dan sikap, serta keterampilan siswa. Hal ini dikarenakan agar peserta didik menjadi warga negara yang baik yakni partisipatif dan bertanggung jawab dalam kehidupan bermasyarakat, berbangsa dan bernegara. Menjadi warga negara yang baik bukan hanya dalam dimensi rasional, tetapi meliputi dimensi spiritual, dimensi emosional dan dimensi social. Dalam Permendiknas No. 22 tahun 2006, kompetensi adalah kemampuan bersikap, berpikir, dan bertindak secara konsisten sebagai perwujudan dari pengetahuan, sikap dan keterampilan yang dimiliki oleh peserta didik. Dari hasil analisis data yang dilakukan maka penguasaan kompetensi kewarganegaraan yang paling baik di peroleh oleh mahasiswa semester 6 yang mendapatkan rata-rata sebesar 76,11, dan di susul oleh semester 4 dengan rata-rata 73 . Hasil tersebut jauh lebih baik dari pada apa yang diperoleh oleh semester 8 yakni 68 dan hasil paling jelek di raih semester 2 dengan rata-rata 58.
Pada dasarnya mata kuliah pendidikan Kewarganegaraan bertujuan untuk meningkatkan kompetensi kewarganegaraan. Namun, hasil ini membuktikan fakta bahwa untuk membentuk kompetensi kewarganegaraan tidak bisa hanya mengandalkan usaha-usaha melalui pendidikan resmi atau melalui mata kuliah pendidikan kewarganegaraan yang hanya di kelas saja. Buktinya penguasaan kompetensi kewarganegaraan yang tinggi pada mahasiswa semester 6 justru di dapatkan karena kegiatankegiatan yang dilakukan mereka di luar kampus seperti aktif berorganisasi, aktif kegiatan sosial dan aktif menjadi tutor belajar bagi anak-anak sekolah. Hal ini dapat menjadi dasar bahwa untuk mengembangkan warganegara menjadi warga negara yang baik, tidak bisa hanya di bebankan pada mata pelajaran seperti pendidikan pancasila dan kewarganegaraan saja. Terbukti semester 8 yang notabene lebih lama menekuni bidang PPKn perolehan nilainya kalah dengan semester 6 dan 4 . Sehingga dapat disimpulkan pembelajaran di kelas tidak cukup untuk membentuk atau meningkatkan kompetensi kewarganegaraan mahasiswa. Dalam meningkatkan kompetensi kewarganegaraan diperlukan beberapa kegiatan mahasiswa yang dapat menunjang terjadinya peningkatan kompetensi kewarganegaraan.

Tabel 4 Rekapitulasi Penilaian Kompetensi Kewarganegaraan

\begin{tabular}{cccccr}
\hline & $\begin{array}{c}\text { Kompetensi } \\
\text { Kewarganegaraan } \\
\text { semester 2 }\end{array}$ & $\begin{array}{c}\text { Kompetensi } \\
\text { Kewarganegaraan } \\
\text { semester 4 }\end{array}$ & $\begin{array}{c}\text { Kompetensi } \\
\text { Kewarganegaraan } \\
\text { semester 6 }\end{array}$ & $\begin{array}{c}\text { Kompetensi } \\
\text { Kewarganegaraan } \\
\text { semester 8 }\end{array}$ \\
\hline \multirow{2}{*}{ N } & Valid & 8 & 11 & 17 & 7 \\
& Missing & 0 & 0 & 0 & 0 \\
Mean & 59.0000 & 73.0000 & 76.1176 & 66.7143 \\
Median & 59.0000 & 73.0000 & 77.0000 & 68.0000 \\
Mode & 56.00 & $72.00^{\mathrm{a}}$ & 80.00 & $64.00^{\mathrm{a}}$ \\
\hline
\end{tabular}




\begin{tabular}{lcccr}
\hline & $\begin{array}{c}\text { Kompetensi } \\
\text { Kewarganegaraan } \\
\text { semester 2 }\end{array}$ & $\begin{array}{c}\text { Kompetensi } \\
\text { Kewarganegaraan } \\
\text { semester 4 }\end{array}$ & $\begin{array}{c}\text { Kompetensi } \\
\text { Kewarganegaraan } \\
\text { semester 6 }\end{array}$ & $\begin{array}{c}\text { Kompetensi } \\
\text { Kewarganegaraan } \\
\text { semester 8 }\end{array}$ \\
\hline Std. Deviation & 6.25643 & 3.16228 & 5.58885 & 3.30224 \\
Minimum & 49.00 & 67.00 & 65.00 & 62.00 \\
Maximum & 68.00 & 77.00 & 86.00 & 70.00 \\
Sum & 472.00 & 803.00 & 1294.00 & 467.00 \\
\hline
\end{tabular}

Sumber: Data hasil penelitian, 2018.

\section{KESIMPULAN}

Hasil dari penelitian menunjukkan bahwa secara keseluruhan mahasiswa PPKn semester VII lebih baik dalam penguasaan kompetensi kewarganegaraan di banding mahasiswa PPKn di semester lain. Hal itu karena dalam kelas mereka telah dikembangkan kultur demokratis seperti aktif dalam pengambilan keputusan publik, ikut dalam diskusi antara mahasiswa dan kampus, aktif dalam kegiatan kemahasiswaan (BEM, HMPS), serta aktif dalam berbagai organisasi sosial di luar kampus. Sehingga secara tidak langsung berbagai aktivitas yang telah mereka lakukan tersebut dapat membantu untuk mengembangkan kompetensi kewarganegaraan.

\section{DAFTAR PUSTAKA}

Alam, B. (2006). Antropologi dan civil society: Pendekatan teori kebudayaan. Antropologi Indonesia, 30(2), 193-200. https://doi.org/10.7454/ai.v30i2.3564

Branson, M. S., \& Quigley, C. N. (1998). The role of civic education. Washinton DC.

Budiarta, I. W. (2013). Penerapan pendekatan belajar catur asrama melalui taksonomi tri kaya parisudha dalam PKn. Bandung.

Budiyono, B., \& Feriandi, Y. A. (2017). Menggali nilai-nilai kearifan lokal budaya Jawa sebagai sumber pendidikan karakter. In Prosiding Seminar Nasional Bimbingan dan Konseling (Vol. 1, hal. 92-103).

Feriandi, Y. A. (2018). Upaya perlindungan lingkungan perspektif konstitusi dan pendidikan kewarganegaraan. Jurnal Pancasila dan Kewarganegaraan, 3(2), 28-35. https://doi.org/http://dx.doi.org/10.24269 /jpk.v3.n2.2018.pp1-9

Fraillon, J., Schulz, W., \& Ainley, J. (2012). ICCS 2009 Asian report: Civic knowledge and attitudes among lower-secondary students in five Asian countries. (J. Fraillon, W. Schulz, \& J. Ainley, Ed.), International Association for the Evaluation of Educational Achievement (IEA) All. Amsterdam: International Association for the
Evaluation of Educational Achievement (IEA). Diambil dari http://search.ebscohost.com/login.aspx?dire $\mathrm{ct}=$ true $\& \mathrm{db}=$ eric $\& A N=\mathrm{ED} 544595 \&$ site $=$ eho st-live

Galston, W. A. (2007). Civic knowledge, civic education, and civic engagement: A summary of recent research. International Journal of Public Administration, 30(6-7), 623-642. ttps://doi.org/10.1080/01900690701215888

Harmawati, Y., Abdulkarim, A., \& Rahmat. (2017). Nilai budaya tradisi Dieng Culture Festival sebagai kearifan lokal untuk membangun karakter bangsa. Journal of Urban Society's Arts, 3(2), 82-95. https://doi.org/10.24821/jousa.v3i2.1477

Huda, K., \& Feriandi, Y. A. (2018). Pendidikan konservasi perspektif warisan budaya untuk membangun history for life. ARISTO, 6(2), 329-343.

Komalasari, K. (2013). Pembelajaran kontekstual: Konsep dan aplikasi. Bandung: Refika Aditama.

Lestari, R. Y. (2016). Peran kegiatan ekstrakurikuler dalam mengembangkan watak kewarganegaraan peserta didik. Untirta Civic Education Journal, 1(2).

Lukitoaji, B. D. (2017). Pembinaan civic disposition melalui model pembelajaran project citizen dalam mata kuliah pendidikan kewarganegaraan 2 untuk menumbuhkan nilai moral mahasiswa prodi PGSD FKIP UPY. Jurnal Moral Kemasyarakatan, 2(2), 102$116 . \quad$ Diambil dari http://weekly.cnbnews.com/news/article.ht $\mathrm{ml}$ ?no $=124000$

Prihastari, A. (2016). Dimensi civic skill dan civic value dalam pembelajaran $\mathrm{PKn}$ analisis isi buku ajar PPKn serta pelaksanaannya di SMA Muhammadiyah 1 Sragen Tahun Pelajaran 2015/2016. Universitas Muhammadiyah Surakarta.

Sherrod, L., Torney-Purta, J., Lehmann, R., Oswald, H., \& Schulz, W. (2001). Citizenship 
and education in twenty-eight countries: civic knowledge and engagement at age fourteen. International Association for the Evaluation of Educational Achievement (IEA). Amsterdam,: Eburon Publisher and IEA. https://doi.org/10.1016/S01933973(02)00143-0

Sugiyono. (2009). Memahami penelitian kualitatif. Bandung: Alfabeta.

Winataputra, U. S., \& Budimansyah, D. (2012). Pendidikan kewarganegaraan dalam perspektif internasional (Konteks, teori, dan profil Pembelajaran) Bandung. Bandung: Widya Aksara Press. 